\title{
TEACHING AND LEARNING METHODOLOGIES IN ENGINEERING EDUCATION IN NIGERIAN UNIVERSITIES
}

OGRI J. USHIE AND JULIE C. OGBULEZIE

(Received 20 February 2017; Revision Accepted 17 May 2016)

\begin{abstract}
The students' outcome in terms of quality of graduates as regard teaching and learning determines whether the existing methods should be reviewed or not. In the recent world ranking of Universities, only University of Ibadan came among the first hundred despite the number of Universities in Nigeria. This calls for general repositioning of the education sector in Nigeria. This paper examines the teaching and learning of engineering in Nigerian Universities and suggests ways of improving engineering education in Nigerian Universities.
\end{abstract}

KEYWORDS: Engineering Education, students' outcome, Tertiary Education and Learning and Teaching methodology.

\section{INTRODUCTION}

The need to enhance learning, which is quality teaching is urgently needed in Nigerian Universities. The skills and knowledge of people in a country is vital as it determines the country's well-being in this era of global knowledge economy. This ensures the quality of learning which are the skills, knowledge and values acquired by students in the Universities that are important for the individual student and community at large. An effective teaching can be defined as the one that leads to improvement in students' outcome as it prepares them for their future success. A great teacher must have the following six features; knowledge of subject area, quality of instruction, classroom climate, classroom management, teachers' belief and professional behaviours [Coe, et al., 2004].

Learning is defined as the way we understand and perceive the world and the meaning derived from it. Learning encompasses mastering abstract principles, remembering factual information, understanding proofs, acquiring methods, approaches and techniques, recognition, debating ideas, reasoning; it is all about change [Fry, et al., 2008]. The need to enhance teaching and learning of graduate of
Electrical Engineering in Nigerian Higher Institutions is illustrated by [Barau, 2015]. The emphasis is on how low graduates are produced due to massive admission of students, shortage of Lecturers, lack of enough students' practical skills as there is little or no practical equipment available for students to carry out their practical and inadequate collaboration between industries and schools.

\section{Tertiary Education}

Globally, the population of students that study in another countries continues to rise. This population was about 5 million in 2014 which more than doubled of the 2.1 million students in 2000 [Benson, 2015 and Jenkins, 2003]. This is due to low standard of tertiary education in most developing countries globally. The Nigerian higher institutions (Tertiary institutions) at present is made up of 79 colleges of education, 47 monotechnics, 71 polytechnics and 122 universities (50 Private, 36 State and 36 Federal), distributed within the six geographical regions. The unevenly distributed federal universities made the Federal Government to establish 9 universities in 2011 to ensure a federal university in all 36 states in the federation [Bamiro, 2012]. The education system in Nigeria

Ogri J. Ushie, Department of Physics, University of Calabar, Calabar, Cross River State, Nigeria.

Julie C. Ogbulezie, Department of Physics, University of Calabar, Calabar, Cross River State, Nigeria. 
has some setbacks due to frequent strikes staged by students, teachers and faculty or different unions. Most of the setbacks are caused by poor funding by the Local, State and Federal Governments which result in shortage of human and materials resources for education. Also, inadequate library resources, lack of qualified teachers and few instructional inputs.

Other Challenges in Nigerian University Systems are:

- Poor foundation of students from secondary school.

- Corruption as the money meant for a particular project is diverted to personal use or over budgeted.

- The accreditation team sent by National University Commission compromise as their report differs from the actual situation in place.

- Deterioration of physical facilities on campus.

- Inadequate research and teachinglearning facilities.

- Overstretching of research and teachinglearning and managerial capacities.

- Massive admission of students not based on quota.

- It is also characterised by social ills: examination malpractices, commercialization of the entire system and cultism.

- Lack of faith in the entire University system.

\section{Teaching Methods}

Teaching is the process aimed at grooming or developing the young. According to [Abanador, et al., 2014] the four common teaching methods are: Participative or Interactive, ContentFocused, Learner-Centred and Instructor or Teacher-Centred [Ashman and Ongwae, 2001].
Teacher-Centred Method: in this approach, the teacher is seen as an expert who masters the subject matter while the learners are presumed to acquire the knowledge from the instructor. It is a lecture method in which learners have little or no involvement in the teaching process and is called "closed-ended" [Ashman and Ongwae, 2001]. This method consists of seven components: developing activities used to guide the students for the lesson, teaching of new material, identifying an objective, questioning the students to get feedback from them regarding their understanding, giving feedback to the student in the needed area of improvement, and giving assignment to students.

Content-Focused Teaching Method: Both the learners and the teacher have to fit into the content of the material that is taught in contentfocused methods of teaching. The skills and information to be taught are very important and emphasis is laid on careful analyses and the clarity of content. In this method, both the learners and the teacher are not critical or cannot alter anything as regard the content. A programmed learning approach is an example [Ashman and Ongwae, 2001].

Learner-Centred Teaching: It is a teaching technique which is concentrated on learning; the central concern of the teacher is on what the students are doing. Learning by doing is a vital aspect of psychomotor domain [Laguador and Dizon, 2013]. The teaching is characterised by involving the students in the messy, hard work of learning. It empowers and motivates students as they have some control in the learning process. Every student shares what he/she has learnt among students. It encourages students' reflection about how and what they are learning. It includes clear learning skills tutoring. Statistic from research findings from national teaching laboratory US [Petty, 2004] shows that the remembering rate of several learning activities is shown in the learning pyramid below: 


\section{Students' memory}
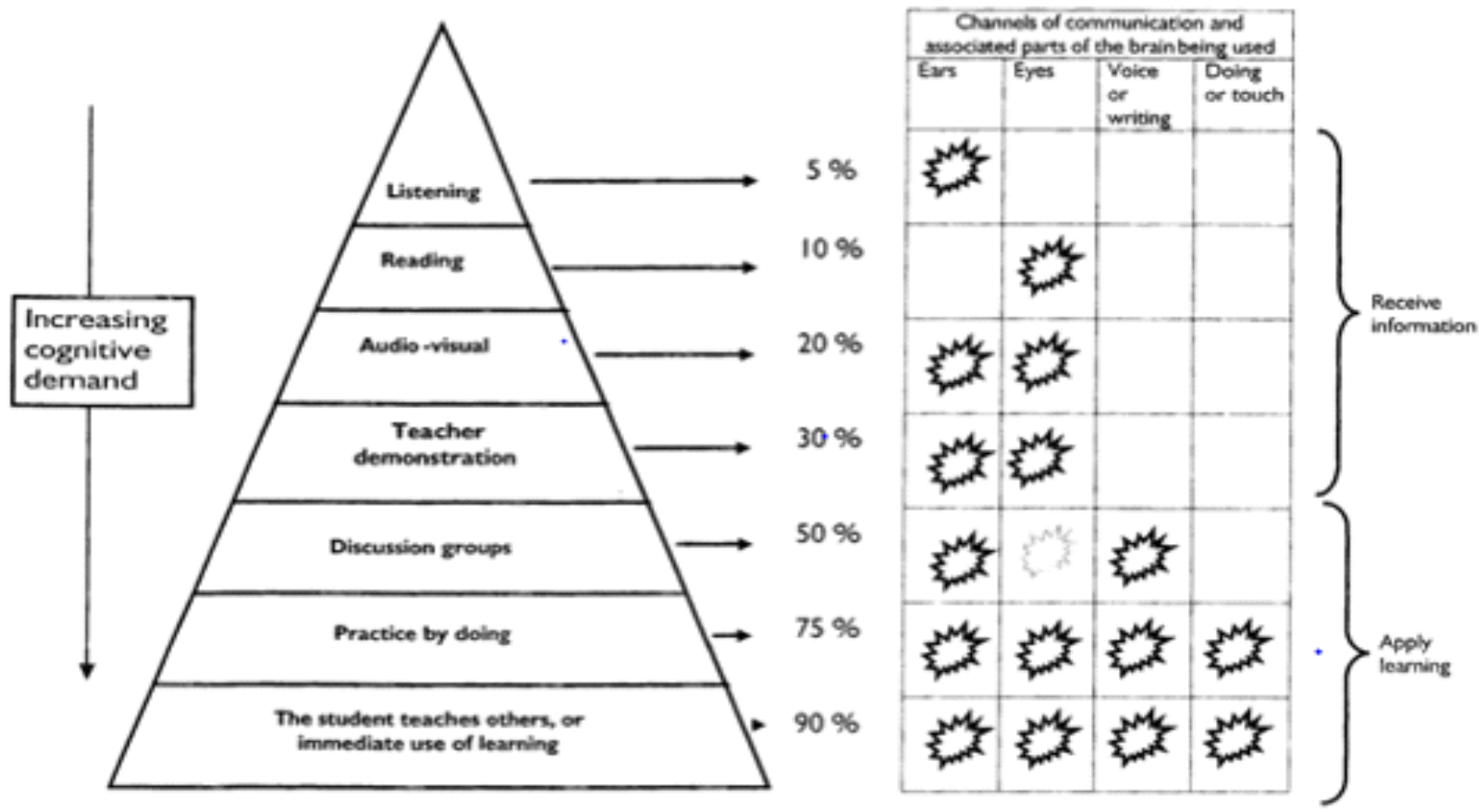

Figure 1: The learning pyramid: Research on the recall rate of different learning activities [Petty 2004].

Figure 1 illustrates that students understand only $5 \%$ of the information by listening during lecture, students get $10 \%$ when they read the information on their own. The students remember $20 \%$ through audio-visual while $30 \%$ assimilate what the teacher taught with demonstration. In teaching with group discussion during class the students get $50 \%$ of the information. Students that practice by doing get $75 \%$ of the information. Also, students that use the information immediately or teach others retained $90 \%$ of the information.

Participatory or Interactive: The interactive or participatory method of teaching is geared towards those factors that enhance learning objective. This method is referred to as learnercentred method.

In addition, [Damodharan, et al., 2007] analysed the innovative and traditional methods of teaching. The setback of traditional methods of teaching are: information transmission is one way, little or no response and feedback; materials are limited to notes and textbooks; less practical aspects or real life time situations but 'plug and play' approach; fate of the subject is determined by the handwriting of lecture; inadequate interactions in classroom; emphases on marks instead of result oriented and learning not for understanding but from memorization. The authors recommend the following innovative approaches: role playing, Z-A approach, wordswords approach and use of humour.

Also, [Duruji, et al., 2014] illustrated students' assimilation while using teaching method in tertiary institution using Covenant University as a case study. It was recommended that the teachers should allow students to contribute effectively in the classroom.

According to [Braun, et al., 2013], to implement innovative methods of teaching in curricula is still a challenge. Innovative methods of teaching in engineering education combine professional practice, academic methods and theory. Applying innovative didactic concepts of teaching in education is an excellent technique to groom students for engineering practice.

Furthermore, [Olorunfemi and Ashaolu, 2008] investigated inadequate practical skill acquired in engineering training, especially in developing nations as the quality of graduates produced cannot fit into the industrial skills required. The study proposed that in restructuring education to aim at industrial requirement, 
teaching methods should connect facilities from both the institutions and industry with resource manpower.

Proper teaching and learning sustain a good standard of education, guaranteed quality graduates who can compete favourably with their counterpart in other countries. Therefore the need to improve the present quality of learning and teaching methodologies in Nigerian Higher Institutions cannot be overemphasised because the effect can be seen from the quality of graduates. Some of these skills can be adopted from developed countries of higher education standard such as the UK and the US. As the government at all levels have their part to play: provision of a conducive environment for learning; teaching and research funding bodies for the development of human resources; the academia also have their role in improving the quality of teaching/learning to meet the current generation need. Teaching in Nigerian Universities, especially engineering education system should go beyond the normal classroom as it builds the students to realise their dreams. Some of these areas that should be critically analysed include:

- Individual students who have special needs in the area of writing, mathematics, and software training need to be considered.

- Students with disability and dyslexia need to be accommodated for in Nigerian University system. Create extra time for students with dyslexia if necessary during test and examination for the slow - learning students. Dyslexia is refereed to as trouble with reading or reading disorder despite normal intelligence.

- There is no general in-house training for both academic and non-academic staff, apart from scholarship awarding bodies like Tertiary Trust Fund (TetFund), Petroleum Technology Development Fund (PTDF), Niger-Delta Development Commission (NDDC) and formal sponsorship of a staff that gains admission within and outside Nigerian university. Such training includes software training (Microsoft Word, Excel, PowerPoint, MATLAB, PSPICE, etc.). The training should be part of the academic calendar so that staff/students can book at their convenient time without conflicting with their lecture or work period. The training should form part of promotion criteria and should be a well- planned programme to encourage staff to attend.

- There should be professional teaching association responsible for skills transfer, developing and ranking of members. This helps the new teachers to equip and create awareness of the teaching professional values. For example in the UK, they have Higher Education Academic (HEA) that have their teachers ranked from associate member to fellow depending on individual contributions toward teaching and learning and level of teaching and learning acquired. Core knowledge of teachers and profession values should be clearly stated.

Among the core knowledge that the association should form and pass on to teachers from time to time include:

- The need to enhance professional practice and quality assurance with a particular focus on teaching and learning.

- Better understanding and knowledge of subject area.

- Required level of the academic programme and techniques for teaching and learning in the subject material.

- How a student learns, both in the subject and generally, for instance, most student these days learn so much through the net. Therefore lecture notes should be posted online.

- The application of appropriate learning methods in class like a projector in all Nigerian higher institutions.

- Effective methods of evaluating teaching.

- Creating awareness in masters and PhD students the need for the association and benefit of the training

Also among professional values that should be formulated and transmitted same to teachers are:

- Respect diverse learning communities and individual learners

- Promote equal opportunity for learners and participation in higher education.

- Use evidence-informed outcomes from research and approaches.

- Recognising the needs of professional practice and should be used as part of criteria for promotion.

- The NUC should from time to time carry out findings for new Engineering courses 
and incorporate them into curriculum and planning, especially courses that facilitate research such as intelligence system courses for simulation such as Neural Network (NN), Particle Swarm Optimisation (PSO), Genetic Algorithm (GA), Genetic Programming (GP), MATLAB, LabVIEW, etc. which are vital tools for engineering design/simulation. Also, resource persons/staff should be sent for training. On their arrival, there should be training the trainer workshop for quick learning as it guarantees transfer of knowledge.

- Research conducted in Nigerian Universities should be translated into teaching. Research led teaching redirects research outcome and apply the findings from research for the benefit of student's learning. The outcome of research is translated into poster, publications, research dissemination and teaching. Research outcome utilisation are itemised below:

- Recent research outcomes are built-into the curriculum.

- Research skills are incorporated into assessment tasks which enable the students to conduct research in their disciplines.

- It also aids the students to learn how to apply the research tools in their disciplines - for instance, simulation software, sophisticated research equipment and primary sources.

- The teaching of the student learning with the application of curriculum take place in a wider context with the feature of culture that values research. In other words, staff academic research publications are displayed on and discussed, students are involved with researchers on specific research projects and students take active part in departmental research [Guerin and Ranasinghe, 2010].

Research-led teaching has advantages and disadvantages listed below starting with the advantages:

- In-depth understanding of the skill base of the discipline
- Enhanced expansion/specialisation of careers paths and transfer of skills for employment

- Develop independent learning in individual

- Increased lateral and critical thinking abilities, appreciation of intellectual property and problem-solving.

- Better source of income (research income/fees)

- Better understanding of academic paths and $\mathrm{PhD}$ research

The disadvantages includes:

- An effective researcher is not necessarily a good teacher

- No such a measure as $50 \%$ teacher $50 \%$ researcher

- It may create biases in lecturer's accounts (support of favoured research area)

- It does not work equally for all research areas

- They are classes at high level [Brew, 2010]

- According to [Marton, et al., 1997 and Boud, 1995] 'students can, with difficulty, escape from the effects of poor teaching, they cannot (by definition, if they want to graduate) escape the effects of poor assessment.' Due to a large number of students in Nigerian Universities, there is little or no assessment and feedback especially in the area of feedback.

\section{CONCLUSION}

This paper critically analysed engineering education in Nigerian Universities; possible problems and areas yet to be considered to enhance education and to make the Nigerian Universities compete with global Universities. Based on the current ranking of Nigerian Universities in which Engineering education as a profession is acquired, the need for improvement in teaching and learning cannot be overemphasised and hence recommend the following to be fully implemented if there must be improvement in ranking.

\section{RECOMMENDATIONS}

- Learning and Teaching Aid: The management of individual University in Nigeria should create different units 
outside the classroom but within the University so that students can book for training or have one- on- one consultation even up to postgraduate level.

- Create a special disability unit that takes care of students with disability and dyslexia. Their role among others includes: verify that the students really fall into these categories.

- In addition to tutorial, incorporate group learning and discussion during class work to enhance quick teaching and learning transfer as students learn faster from themselves.

- Develop effective learning environment and approaches to students support and guidance. If a learning environment is void of intimidation, harassment and undue suppression will afford the student to learn freely and contribute effectively to class activities.

- Engage in continuing professional developments in engineering disciplines within the Universities.

- A Teaching Profession should have a Professional Association responsible for skills transfer, developing and ranking of members. This helps the new teachers to equip and create awareness of the teaching professional values. For example in the UK, they have Higher Education Academic (HEA) that have their teachers ranked from associate member to fellow depending on individual contributions toward teaching and learning and level of teaching and learning acquired.

- Design and planning of learning activities and program of study with the current world technology.

- There should be check and balances between examination questions and notes covered in class/learning received in class for all levels. The standard of learning/teaching in the class/notes received should be compared to the examination questions at all levels in engineering degree. This will reduce substandard teaching and to ascertain that student's examination questions do not go outside the scope of teaching/learning and hence will reduce corruption. This is different from external examination system which is mostly only concerned with final students.

- Also, the examination scripts after marking should be cross checked with the marking scheme by an anonymous person. This will ensure that all the lecturers mark and access all students with equal standard with fair and equal treatments. It will also reduce corruption in Nigerian engineering education system.

- Group project that cut across all fields of engineering (year 2 group project) should be encouraged. The project will aid the students to work as a team and serve as training to them to know that the engineering profession is a team work.

- Research lead teaching or incorporating findings into Teaching: The need for a country like Nigeria to adopt research-led teaching can be demonstrated by the fact that graduates from a "research-led" universities perform better than graduates from universities with a teaching focus only.

- Assessment/Feedback for Learning: The classes should be sub-divided into manageable sizes with more man power for proper assessment and feedback. Feedbacks received by students on coursework provide a clear guidance as regard improving performance as well as motivating them to study. Also, most students will perform better if they receive feedback regarding exam performance.

- Practical Oriented Training: Engineering teaching and learning should go beyond theoretical teaching, there should be a well-established and functional workshop where components or materials for practical are always available for demonstration of whatever is thought in the class. This will equip the students with the required industrial skills for engineering practice.

\section{REFERENCES}

Abanador, J. R., Buesa, G. C. D., Remo, G. M. L and Manibo, J., 2014. Teaching Methods and Learning Preferences in the Engineering Department of an Asian University. International Journal of Academic 
Research in Progressive Education and Development, 3, (1): 1-15.

Ashman, M and Ongwae, M., 2001. Trainer's Handbook - A 14 days Teaching Methodology Course, Trainer's Handbook, Kenya.

Bamiro, O. A., 2012. "Tertiary Education in Nigeria and the Challenge of Corporate Governance." 3.

Barau, S., 2015. "Enhancing Teaching and Learning of Electrical Power Engineering in the Nigerian Tertiary Institutions." International Journal of Learning and Teaching, 1, (1): 55-58.

Benson, K., 2015. "International trends in higher education 2015. "University of Oxford, The International Strategy Office. 5.

Boud, David., 1995. "Assessment and learning: contradictory or complementary." Assessment for learning in higher education, 35-48.

Braun, Bruno O., TÜV Rheinland A. G., and Büro des Vorsitzenden des Aufsichtsrats., 2013. "Innovative Methods in Engineering Education." CAETS/HAE Symposium. 1-4.

Brew, A., 2010. Research-Led Teaching Summary of article "Understanding Research-Led Teaching", HERDSA News, 25, (1): 1-2.

Coe, R., Aloisi, C., Higgins, S., and Major, L. E., 2004. What makes great teaching. Review of the underpinning research, Centre for Evaluation and Monitoring, Durham University and The Sutton Trust, 2-3.

Damodharan, V. S and Rengarajan, V., 2007. "Innovative methods of teaching." Learning Technologies and Mathematics Middle East Conference, Sultan Qaboos University, Muscat, Oman, 1-16.

Duruji, M. M., Dominic, E. A., Segun, J., Olanrewaju, I. P and Uche O., 2014. "Teaching Method and Assimilation of Students in
Tertiary Institutions: A Study of Covenant University, Nigeria", 99. 5116-5126.

Fry, H., Steve, K and Stephanie, M., 2008. A handbook for teaching and learning in higher education: Enhancing academic practice. Routledge, New York and London,

Guerin, C and Ranasinghe, D., 2010. Why I Wanted More: Inspirational Experiences of the Teaching-Research Nexus for Engineering Undergraduates, Journal of University Teaching \& Learning Practice, 7, (2): Article 8 (1-24).

Jenkins, A., 2003. Reshaping teaching in higher education: Linking teaching with research. Psychology Press, A. London, Kogan Page. 210.

Laguador, J. M and Dizon, N. C., 2013. Academic Achievement in the Learning Domains and Performance in Licensure Examination for Engineering Among LPU's Mechanical and Electronics Engineering Graduates, International Journal of Management, IT and Engineering, 3(8): 347-378.

Marton, F and Booth, S., 1997. Learning and Awareness, Mahwah, NJ: Lawrence Erlbaum Associates,

Olorunfemi, A. I and Ashaolu, M. O., 2008. A Pragmatic Approach in Engineering Education Teaching Methods and Industry Partnership. In Proc. of 30th SEFI Annu. Conf, pp. 1-6,

Petty, G., 2004. Teaching today: A practical guide. Nelson Thornes, 